\title{
Taxonomic notes on the typology of four species of genus Notodiaptomus Kiefer, 1936 (Copepoda: Calanoida: Diaptomidae)
}

\author{
Luis José de Oliveira Geraldes-Primeiro ${ }^{1 *}$, Joana D'Arc de Jesus Pinto ${ }^{2}$, Raimundo Erasmo Souza Farias ${ }^{3}$ \\ \& Edinaldo Nelson dos Santos-Silva \\ ${ }^{1}$ Instituto Nacional de Pesquisas da Amazônia, Programa de Pós-Graduação em Biologia de Água Doce e \\ Pesca Interior, Coordenação de Biodiversidade, Laboratório de Plâncton, Manaus, AM, Brasil. \\ ${ }^{2}$ Museu de Zoologia da Universidade de São Paulo, Coleção Carcinológica, Laboratório de Carcinologia, \\ São Paulo, SP, Brasil. \\ ${ }^{3}$ Instituto Nacional de Pesquisas da Amazônia, Programa de Pós-Graduação em Biologia de Água Doce e \\ Pesca Interior, Manaus, AM, Brasil. \\ ${ }^{*}$ Corresponding author: Luis José de Oliveira Geraldes-Primeiro, e-mail: geraldesprimeiro@gmail.com \\ GERALDES-PRIMEIRO, L.J.O., PINTO, J.D.J., FARIAS, R.E.S., SANTOS-SILVA, E.N. Taxonomic notes on \\ the typology of four species of genus Notodiaptomus Kiefer, 1936 (Copepoda: Calanoida: Diaptomidae). \\ Biota Neotropica 21(1): e20201073. https://doi.org/10.1590/1676-0611-BN-2020-1073
}

\begin{abstract}
During a taxonomic study of the genus Notodiaptomus Kiefer 1936, taxonomic materials were located for $N$. iheringi, $N$. spinuliferus, $N$. henseni and $N$. deitersi, and all had their status investigated. Inconsistencies were found and are reported in this note, from the original details to the current typological situation. Nomenclatural conformations and new types are specified. These reinforce the taxonomic validity of the species, recently redescribed in other research. Thus in this note the neotype to N. iheringi, N. spinuliferus, and N. henseni, and provide a topotype to $N$. deitersi are defined.
\end{abstract}

Keywords: Neotropical Copepods; Typification; Taxonomic stability; Nomenclature Zoological Code.

\section{Nota taxonômica sobre a tipologia de quatro espécies de Notodiaptomus Kiefer, 1936 (Copepoda: Calanoida: Diaptomidae)}

Resumo: Durante o estudo taxonômico do gênero Notodiaptomus Kiefer (1936), N. iheringi, N. spinuliferus, $N$. henseni e $N$. deitersi tiveram seus materiais taxonômicos localizados e investigados. Inconsistências foram observadas e são relatadas nesta anotação, desde os detalhamentos originais até a atual situação tipológica. Conformações nomenclaturais e novos tipos são especificados e reforçam a validade taxonômica destas espécies, neótipos para $N$. iheringi, $N$. spinuliferus, $N$. henseni e topótipo para $N$. deitersi.

Palavras-chave: Copépodes neotropicais; Tipificação; Estabilidade taxonômica; Código de nomenclatura zoológica. 


\section{Introduction}

Notodiaptomus is a genus of Copepoda Edwards, 1840 originally proposed by Kiefer (1936). A species group from "Nordestinus complex" of the genus Diaptomus (sensu lato) formed the initial basis for the formation of this genus (Wright, 1935), originally with 11 and, currently, 43 valid taxa (WoRMS 2020).

Amongst these, Notodiaptomus iheringi (Wright, 1935), Notodiaptomus spinuliferus Dussart and Matsumura-Tundisi in Dussart, 1985, Notodiaptomus henseni (Dahl, 1894) and Notodiaptomus deitersi (Poppe, 1891) were described, respectively, for the northeast, southeast, midwest and northern areas of Brazil. Notodiaptomus iheringi, $N$. henseni and $N$. deitersi were recently redescribed by Santos-Silva et al. (2015), who established taxonomic limits, but without resolving problems associated with type specimens. Notodiaptomus spinuliferus, which has gained a heterogeneous description over time (Dussart and Matsumura-Tundisi 1986; Paggi 2001; Matsumura-Tundisi 2008), has nonconformities in relation to the original description and a missing holotype, all of which weakens its taxonomic validity and status.

As part of a widest taxonomic revision of the genus Notodiaptomus these species were tracked through the literature, and located at the Museum of the Carcinological Collection of Zoology from the University of São Paulo, and the collection of the Invertebrate Zoology Department from the Smithsonian Institution National Museum Natural History, Washington D.C. (NMNH), where their type-series were accessed and examined. Specimens of $N$. ihering $i$ and the type-material of $N$. spinuliferus were found, but not those of $N$. henseni or $N$. deitersi, although these were reported as being in this collection (Santos-Silva et al. 2015). All located specimens were analyzed. Those said to be in the collection, but not found, were tracked via the original literature. Finally, four species were found to have typological inconsistencies and required typological adaptation, because they possess some level of damage to their stored material-type.

Accordingly, we provide here definitions of the $N$. iheringi, $N$. spinuliferus, $N$. henseni and $N$. deitersi type-series. Additionally, we provide comments on the state of preservation, storage and disposal of the analyzed type-material present in of the visited taxonomic collections.

\section{Materials and Methods}

Specimens analyzed in this study came from the Carcinological Collection of the Museum of Zoology of the University of São Paulo (MZUSP) and the collection of the Invertebrate Zoology Department of the Smithsonian Institution National Museum Natural History, Washington D.C. (NMNH). The state of preservation and conditions of the preserved material were investigated using the original taxonomic records and applying the norms of the International Code of Zoological Nomenclature (ICZN 2012). To assist analysis, a Leica MZ12.5 trinocular optical stereomicroscope and a Leica CTR5000 10x-100x trinocular optical microscope with attached Leica DFC450 camera and Leica Application Software (LAS) were used for images and micrographic measurements of specimens, all accessed with prior authorization from the MZUSP taxonomic collections curator. Permanent slide dissection and assembly procedures followed Kihara \& Rocha (2009): lactophenol as medium, whole coverslips $(24 \times 24$ $\mathrm{mm})$ on self-adhesive plastic wedges and Entellan ${ }^{\circledR}$ Rapid MicroMounting Medium. For wet preservation, 70\% alcohol was either deployed or renewed. All material examined, produced or added (i.e., "Additional Material") in this study continues to form part of the initially accessed taxonomic collection, $N$. spinuliferus, $N$. henseni and $N$. deitersi in the Museum of Zoology at the University of São Paulo (São Paulo, Brazil), and N. iheringi in the Smithsonian Institution National Museum Natural History (Washington DC, USA).

\section{Results}

Based on the analyzes carried out in the scientific collection of the MZUSP, on focus to the species $N$. deitersi, $N$. iheringi, $N$. henseni, and $N$. spinuliferus, the descriptive characterization of the respective type-material becomes updated as follows:

Notodiaptomus deitersi (Poppe, 1891). Assigned collection: MZUSP. Deposition label: Topotype. Access code informed: 12.823. Deposit details: $20 \widehat{\jmath}$ and 20 우 우 (in alcohol $70 \%$ ), adults, on 30.X.1996, collected by V.P. da Silva. Situation: not existent. Resolution employed: supplementation of material [by this designation]. Additional material information: BRAZIL: MATO GROSSO. Baía Pedra Branca (15²7’44”S 6006’44”O), Vila Bela da Santíssima Trindade [431 km from Cuiabá]. Specimens of adult colleted by V. P. da Silva, on 30.X.1996. Additional material label: Topotype. $20 \hat{\partial} \hat{\partial}$, undissected, preserved wet (MZUSP 40395) and $20 ㅇ ㅜ$, undissected, preserved wet (MZUSP 40395). Confirmed by

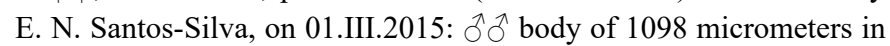
mean length $(\mathrm{N}=20)$, variation between 1060 and 1166 micrometers; 우우 body of 1148 micrometros mean length $(\mathrm{N}=20)$, variation between 1113 and 1176 micrometers, both excluding caudal setae. Deposited in: Carcinological Collection of the Museum of Zoology of the University of São Paulo (MZUSP), São Paulo, Brazil. Ecology: organism typical of ponds, lakes and bays environments.

Notodiaptomus iheringi (Wright, 1935). Assigned collection: MZUSP. Deposition label: non-type material. Access code informed: (a) MZUSP 6192, (b) MZUSP 6192 and (c) MZUSP 6193. Deposit details: $4 \hat{\jmath} \widehat{\partial}$ adult (a), 3 우 adult (b), and 4 juveniles [sex not provided] (c), all in alcohol, un-dissected. Situation: destroyed exemplars [except juveniles]. Resolution employed: Neotype designation from material from the locality-type existing in the MNHN [by this designation]. Additional material information: BRAZIL, PARAÍBA. Açude Puxinanã (Puxinanã Reservoir), vila de Puxinanã, close to Campina Grande [type-locality]. Adult specimes colleted and determined by S. Wright, no date, deposited in the Smithsonian Institution National Museum Natural History (MNHN). Additional material label: Neotype. $1 \widehat{\jmath}$, un-dissected, preserved wet (USNM 1548280). Topotype. $1 \delta$, un-dissected and $2+$ $ᄋ$, un-dissected (USNM 79542). Confirmed by C. WALTER, 04.XI.2019: neotype 1100 micrometers excluding caudal setae, prosoma 800 micrometers. Deposited in: Invertebrate Zoology Department of the Smithsonian Institution National Museum Natural History (NMNH), Washington D.C. Ecology: an organism typical of limnetic environments, encountered in reservoirs, lakes, rivers and streams.

Notodiaptomus henseni (Dahl, 1894). Assigned collection: MZUSP. Deposition label: Neotype. Access code informed: none. Deposit details: $1 \hat{\jmath}$ adult, in alcohol, un-dissected. Situation: nonexistent. Resolution employed: supplementation of material [by this designation]. Additional material information: BRAZIL: PARÁ. Igarapé Uruazinho [Uruazinho stream] ( $0^{\circ} 04^{\prime} 03$ ”S 4708'56”O), Maiauatá, rio Tocantins waterfall region. Specimen of an adult 
semaphoronte colletad and determined by M. N. Cipólli \& M. A Juliano de Carvalho, on 27.VIII.1970. Additional material label: Neotype. 10 , undissected, preserved in alcohol 70\% (MZUSP 40393). Topotype. 10 우, by this designation, undissected, preserved wet (MZUSP 40394), 10 $\widehat{\partial}$, un-dissected, preserved in alcohol 70\% (MZUSP 40394). Confirmed by E. N. Santos-Silva, on 01.III.2015: neotype 1208 micrometers excluding caudal setae, prosoma 890 micrometers. Deposited in: Carcinological Collection of the Museum of Zoology of the University of São Paulo (MZUSP), São Paulo, Brazil. Ecology: organism typical of river mouths, reservoirs, marginal lagoons, lakes, and streams environments.

Notodiaptomus spinuliferus Dussart and Matsumura-Tundisi in Dussart, 1985. Assigned collection: MZUSP. Deposition label: (a) holotype and (b) paratypes. Access code informed: (a) MZUSP 6969 , (b1) MZUSP 6970, and (b2) MZUSP 6971. Deposit details: (a) $1 \delta$ adult, un-dissected, permanently mounted on slide [one]; (b1) $1 \hat{\delta}$ adult, un-dissected, permanently mounted on slide [one], and (b2) $2 \hat{\delta} \hat{\jmath}$ and 5 우우, un-dissected, preserved in alcohol 70\%. |Material collected and determined by Dussart \& Matsumura-Tundisi, on 14.III.1979. Situation: holotype missed [broken slide], and paratypes viable paratypes for exam. Resolution employed: supplementation of material [by this designation]. Additional material information: BRAZIL: SÃO PAULO. Ilha Solteira reservoir (20¹7'58”S 5108’32”O), Paraná river, frontier between the states of São Paulo and Mato Grosso do Sul. Specimens adult collected and determined by Dussart \& MatsumuraTundisi, on 14.III.1979 [same type-locality]. Additional material label: Neotype. 19 adult, undissected, preserved in alcohol 70\% (MZUSP 40049). Paratype. $1 \delta$ adult, un-dissected, permanent mount (MZUSP 6970); $1 \delta$ adult, dissected, mounted on 5 permanent slides (MZUSP 6971), 1 ㅇ adult, dissected, mounted on 4 permanent slides (MZUSP 6971), $1 \delta$ and $3 \circ \circ$, adult, un-dissected, preserved in alcohol $70 \%$ (MZUSP 6971). Confirmed by L. J. O. Geraldes-Primeiro, on 05.IX.2019: neotype body 1260 micrometers (excluding caudal setae), prosoma 1001 micrometers; male 1079 micrometers $(\mathrm{N}=3)$ excluding caudal setae, prosoma 761 micrometers $(\mathrm{N}=3)$, smaller and finer than the female; female body 1231 micrometers $(\mathrm{N}=4)$ excluding caudal setae, prosoma 998 micrometers $(\mathrm{N}=4)$. Deposited in: Carcinological Collection of the Museum of Zoology of the University of São Paulo (MZUSP), São Paulo, Brazil. Ecology: an organism typical inhabitant of standing waters.

\section{Discussion}

Morphological examination in $N$. iheringi, N. spinuliferus, $N$. henseni, and $N$. deitersi revealed related inconsistencies to the original records of the types-specimens of these species (i.e. typological records), some of which were non-existent, disappered, or danified.

The specimens of Notodiaptomus ihering $i$ were the first examined and 11 individuals assigned to the taxon were found to be partially or completely damaged. Adult male semaphoronte specimens were the only ones for which morphometric measurements were possible, though these had damaged morphologies that made them inappropriate for detailed examination. Examination allowed us to determine that the current preservation status of the material was the result of an unsuccessful attempted at alcohol rehydration.

Notodiaptomus iheringi was described by Wright in 1935, initially from Diaptomus sensu lato, with an unspecified holotype and non- specified location, probably with non-existent type material (Reid 1991). Kiefer (1936) in creating Notodiaptomus transferred several taxa to this genus, which has since then undergone some repositioning (Dussart 1985; Rolla et al. 1990) to achieve the present status. Reid (1985) provided a redescription to the species from material from sites in Rio de Janeiro state, Lagoa da Saudade (21³8'17'S 41¹1'06”O), precisely. It is likely the material of the MZUSP collections accessed and analysed during the current study, especially the females, from which we could identify only preserved organic residues.

Through the work of Reid (1991), we tracked the existence of material from the species type locality, in the NMNH, under code 79542. SantosSilva et al. (2015) informed that from this material it would be specified neotype of the taxon, which we verified never to have occurred. Thus, due to the inexistence of the type material, a poor condition in the existing MZUSP specimens, and the existence of specimens from the type locality originally to the taxon, we designate the neotype of the specie (USNM 1548280), from of the material existing at the NMNH' biological collection.

The current records, therefor, satisfy the conditions required by article 75, recommendation 75 of the ICZN (2012), which defines these conditions as necessary presuppositions for typological designation, which is hereby assigned to fix and give greater stability to the $N$. iheringi.The inconsistencies observed in Notodiaptomus spinuliferus were of different sort and concerned the disappearance of the typespecimen and specific non-observance of the taxonomic availability criteria stated in the nomenclatural code.

Notodiaptomus spinuliferus was described by Dussart (1985), with attributed authority to Dussart \& Matsumura-Tundisi in this report. However, even if the specified assignment is as given in Dussart " $c f$. Dussart \& Matsumura-Tundisi, sous presse", the description offered by Dussart (1985) meets the availability (article 11) and publication (article 8) criteria of the ICZN (2012), and therefore it is valid to consider it as the nomenclatural act for this taxon. There are several misquoted citations for the species authority record which, in compliance with ICZN Article 51.2 (51) recommendation 51E, should be cited invariably as Notodiaptomus spinuliferus Dussart \& Matsumura-Tundisi in Dussart, 1985.

Regarding the typological analysis of the material deposited by Matsumura-Tundisi \& Dussart at the MZUSP, the precarious preservation state in which the holotype was stored (on a permanent slide) (Figure 1)

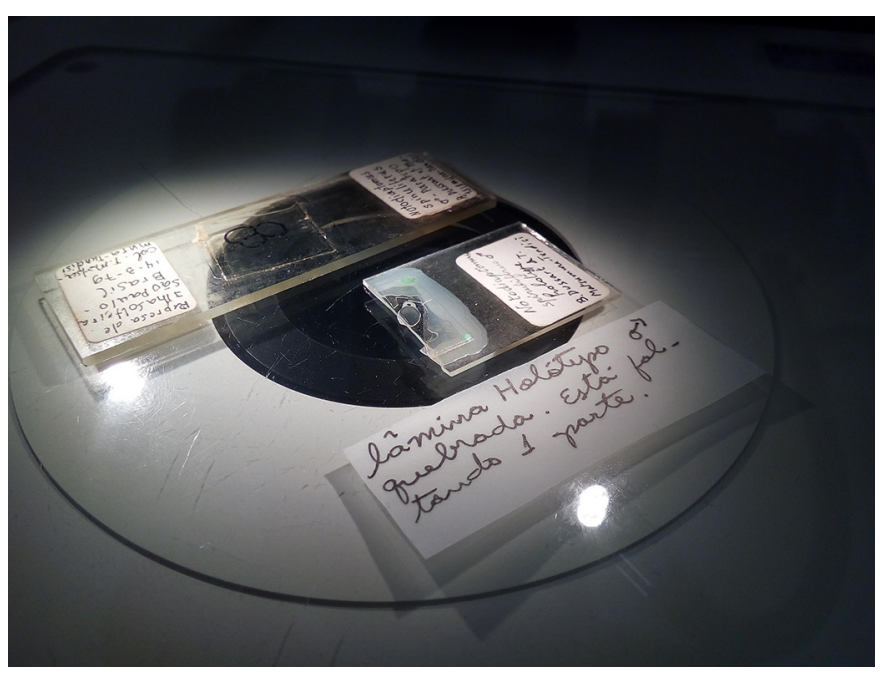

Figure 1. Type material of Notodiaptomus spinuliferus, condition of preservation of the holotype (MZUSP 6969) and paratype (MZUSP 6970). 
makes it unsuitable for accurate and detailed morphological examination. The specimen in question would be a male and only the original slide, deposited in 1985, was found. This was fragmented and probably, because if this, with the type specimen missing. Of the eleven paratypes reported as being in existance (these being: one slide containing a male [MZUSP 6970], and five males and five females [MZUSP 6971]), only eight have been confirmed as still existant: one male (MZUSP 6970), two males (MZUSP 6971), and five females (MZUSP 6971). Of these, one male and one female were identified, dissected and mounted on nine permanent slides, five male-containing slides and four female-containing slides, remaining as the paratypes.

A female from the MZUSP 6971 lot was selected, examined and deposited as an undissected specimen in alcohol $70 \%$, as the neotype MZUSP 40049. This designation was made in accordance with Art. 75 of ICZN (2012). All procedures for dissection and assembly of permanent slides followed the recommendations (Kihara \& Rocha, 2009) for type material that are designed for future taxonomic examinations.

Notodiaptomus henseni and $N$. deitersi were taxa with type material reported by Santos-Silva et al. (2015) to be housed in the MZUSP. However, these accessions appear non-existent, and therefore could not be examined. The type locality for $N$. hensen $i$ was not specified clearly in Dahl (1894), but Santos-Silva et al. (2015) provided evidence that makes the mouth of the Tocantins river, Pará state, the most likely original site. Thus, a specimen was selected for designation as a neotype of the species (MZUSP 40393) and added topotypes to the MZUSP collection, all them derived from the material collected at the above-mentioned location, during the Permanent Amazon Expedition (PAE) in 1970, and located in the National Amazon Research Institute's Plankton Laboratory collection.

For $N$. deitersi, 20 males and 20 females under code MZUSP 12.823 indicated by Santos-Silva et al. (2015) as topotype of the species could not be located. This is the type species of the genus Notodiaptomus and was intended by Santos-Silva et al. (1999) and Santos-Silva et al. (2015) to provide taxonomic stability. However, through the current contribution, we additional and specified taxon material for the MZUSP, which now that conforms to the information originally specified to paratypes of the taxon (Santos-Silva et al., 1999).

Therefore, we concluded that the typological situation of the investigated taxa is properly stabilized. Thus, all species possess existente type-material, localized, and defined as evidence of their morphological patterns. This grants the necessary nomenclatural validity for the taxa, and it is essential for further accuracy morphological investigations.

\section{Acknowledgments}

Our great to the Museum of Zoology of the University of São Paulo, nominally to Dr. Marcos Domingos Siqueira Tavares, the Curator of the Carcinological Collection, and Maria José de Souza Coelho, technical support. To Dr. Chad Walter, curator of the Invertebrate Zoology Department Collection of the Smithsonian National Museum of Natural History, who kindly conducted typological selection. To Programa de Pós-Graduação Biologia de Água Doce e Pesca Interior (PPG-BADPI) of the Instituto Nacional de Pesquisas da Amazônia (INPA) for the financial support provided for this study, and finally to the anonymous reviewers that contributed consistently to the qualification of this scientific report.

\section{Author Contributions}

Luis José de Oliveira Geraldes-Primeiro: Responsible for the development of the study, for taxonomic examinations, acquisition and interpretation of data, writing of this proposal, and submission of this manuscript.

Joana D'Arc de Jesus Pinto: As curator of the type-material at carcinological collection of the Museum of Zoology of São Paulo, the co-author was responsible in obtaining the material examined in this study. Futhermore, she was directly responsible for the records and catalogueupdates of the specimens examined and added to the scientific collection.

Raimundo Erasmo Souza Farias: The co-author participated in the interpretation of the analysis of the data obtained and in the writing of the paper. He was a key member of the intellectual consistency of this study and relevant to the critical review of all content.

Edinaldo Nelson dos Santos-Silva: The co-author was decisive in obtaining part of the data and directly examined one of the species presented in this study. Futhermore, he was participating in the critical review and development of intellectual content.

\section{Conflicts of Interest}

The authors declare that have no conflict of interest that might constitute an embarrassment to the publication of this article.

\section{References}

Dahl, F. 1894. Die Copepodenfauna des unteren Amazonas. Berichtung der Naturforschenden Gesellschaft zu Freiburg, 8:1023.

Dussart, B.H. 1985. Sur quelques copépodes d'Amerique du Sud, V. Diaptomidae. Archiv für Hydrobiologie, 103:201-215.

Dussart, B.H. \& Matsumura-Tundisi, T. 1986. Nouvelles espècils de calanoïdes du Brèsil. Revista Brasileira de Biologia, 46(1):249-255.

Edwards, M.H. 1840. Ordre des Copepodes. In Histoire naturelle des Crustaces, comprenant l'anatomie, la physiologie et la classification de ces animaux, 3:411-529. https://www.biodiversitylibrary.org/page/16103940

ICZN. 1999. International Code of Zoological Nomenclature $=$ ICZN (4th ed.). International Trust for Zoological Nomenclature, London. Available from http://www.nhm.ac.uk/hosted-sites/iczn/code/

Kiefer, F. 1936. Über die Systematik der Südamerikanischen Diaptomiden (Crustacea Copepoda). Zoologischer Anzeiger, 116:194-200.

Kihara, T.C., \& Rocha, C. 2009. Técnicas para estudo taxonômico de copépodes harpacticóides da meiofauna marinha. Editora Asterisco.

https://www.researchgate.net/publication/259821177_Tecnicas_para_estudo_ taxonomico_de_copepodes_harpacticoides_da_meiofauna_marinha

Matsumura-Tundisi, T. 2008. Rectification of description of Notodiaptomus spinuliferus Dussart and Matsumura-Tundisi, 1986. Brazilian Journal of Biology, 68(3): 683-684

Paggi, J.C. 2001. Clarification of the taxonomic status of Notodiaptomus anisitsi (Daday, 1905) and related species, with description of a new species from Argentina (Crustacea: Copepoda: Diaptomidae). Hydrobiologia, 453/454:549-564. https://link.springer.com/ article/10.1023/A:1013199713987

Poppe, S.A. 1891. Ein neuer Diaptomus aus Brasilien. Zoologische Anzeiger, $14: 248-250$

Reid, J.W. 1985. Calanoid copepods (Diaptomidae) from coastal lakes, State of Rio de Janeiro, Brazil. Proceedings of the Biological Society of Washington, 98:574-590. 
Reid, J.W. 1991. The Stillman Wright Collection of Copepoda (Crustacea) from South America in the National Museum of Natural History, Smithsonian Institution. Proceedings of the Biological Society of Washington, 104:736741. https://www.biodiversitylibrary.org/part/46824\#/summary

Rolla, M.E., Dabés, M.B.G.S., França, R.C. \& Ferreira, E.M.V.M. 1990. Aspectos Limnológicos do Reservatório de Volta Grande, Minas Gerais/São Paulo. Acta Limnologica Brasiliensia, 3:219-244.

Santos-Silva, E.N., Boxshall, G.A. \& Rocha, C.E.F. 1999. The Neotropical genus Notodiaptomus Kiefer, 1936 (Calanoida: Diaptomidae): redescription of the type species Notodiaptomus deitersi (Poppe, 1891) and designation of a neotype. Studies on Neotropical Fauna and Environment, 34: 114-128.

Santos-Silva, E.N., Rocha, C.E.F. \& Boxshall, G.A. 2015. Revisão das espécies do "complexo Nordestinus" (Wright, 1935) de Notodiaptomus Kiefer, 1936 (Copepoda: Calanoida: Diaptomidae). Biologia Geral e Experimental, 13:1-115. http://www.biologiageralexperimental.bio.br/pdfs-edicoes/ Volume-13-Numero-2.pdf
WoRMS Editorial Board. 2020. World Register of Marine Species. Available from http://www.marinespecies.org at VLIZ. Accessed 2020-09-24. doi: $10.14284 / 170$

Wright, S. 1935. Three new species of Diaptomus from Northeast Brazil. Anais da Academia Brasileira de Ciências, 7: 213-233.

Received: 06/07/2020

Revised: 02/12/2020

Accepted: 23/12/2020

Published online: 01/02/2021 